\title{
Clarence Dutton's Geology
}

\author{
K. R. Aalto \\ Department of Geology \\ Humboldt State University, Arcata, CA 95521, U.S.A. \\ email:kra1@humboldt.edu
}

\begin{abstract}
Clarence Edward Dutton (1841-1912), a Yale University graduate, served in the Civil War and, as a captain in the United States Army, was detailed for duty with John Wesley Powell's U.S. Geographical and Geological Survey of the Rocky Mountain Region, and later, the U. S. Geological Survey. He spent ten years in geological research in the Colorado Plateau region, studying its geomorphic and stratigraphic evolution, and coined the term "isostasy". His monograph on the Tertiary History of the Grand Cañon District is renowned for its particular charm, with sublime landscape descriptions and superb illustrations. Later, Dutton undertook studies in volcanic geology in Hawaii, the Cascades and on the Colorado Plateau. Dutton studied the effects of the catastrophic Charleston Earthquake of 31 August 1886, and later engaged in irrigation research in the West. He critically reviewed many major geologic concepts, including causes of volcanism, earthquakes and, especially, orogeny. His pioneering work on stratigraphy, geomorphology, isostasy and seismology place him in the forefront of $19^{\text {th }}$ Century researchers and reflected his ability generalize from field observations and formulate principles that constitute explanations of the observed facts.

Keywords: Dutton, Colorado Plateau, Charleston earthquake, isostasy, seismology
\end{abstract}

\section{INTRODUCTION}

Clarence Edward Dutton (1841-1912), a pioneer in the geologic investigation of the American West, had a somewhat circuitous career path. At Yale University his interest was in literature. His drift into geology was very much the result of having met John Wesley Powell who engineered Dutton's assignment his western survey and, eventually, the U. S. Geological Survey; this despite Dutton's lifelong military commission (Anderson, 1977; Stegner, 2006). We witness a young man's drift among competing careers and the influence of a mentor in establishing his life's mission, so often the case of many in science. The importance of Dutton's pioneering work in the American West on its popularization and the eventual protection of national treasures such as the Grand Canyon and Crater Lake as national parks cannot be overemphasized. Herein we witness the power of the written word and artistry in Dutton's many scientific monographs. For these he received acclaim, both in North America and abroad, as having produced works of literature as well as science (Stegner, 2006). This heightened public interest in geology, thus Dutton by virtue of his superlative literary skills may be considered a pioneer in popularizing science. I will first provide a brief biographical sketch, then a review of Dutton's principal research accomplishments and lastly discuss how he progressed from observation to inference about large-scale geologic processes. 


\section{BIOGRAPHICAL SKETCH}

Dutton was born in Connecticut and trained in the ministry and was graduated from Yale University in 1860 (Figure 1). He entered Yale at age fifteen and displayed a consistently average performance in traditional classical curriculum, ranked $88^{\text {th }}$ in a class of 110 seniors, but especially enjoyed creative writing (Anderson, 1977; Stegner, 2006; Orme, 2007). He excelled in both gymnastics and crew, was a superb chess player and eventually received senior prizes for mathematics and the Yale Literary Medal for an essay on novelist Charles Kingsley (Diller, 1912). He served in the Civil War and, when later commissioned $2^{\text {nd }}$ lieutenant in the U. S. Army Ordinance Corps stationed near Albany, New York, had occasion to study paleontology under James Hall (1811-1898) and Robert Parr Whitfield (1828-1910), as well as undertake chemical research at the Bessemer Steel Works. His first scientific paper, The Chemistry of the Bessemer Process, was read at an American Association for the Advancement of Science in 1869 (Anderson, 1977). Based upon this success Dutton was selected as a trustee of the Rensselaer Polytechnic Institute and courted to serve as a professor of mechanical engineering. However, the Secretary of War refused to terminate his military commission and throughout his career he remained attached to the United States Army.

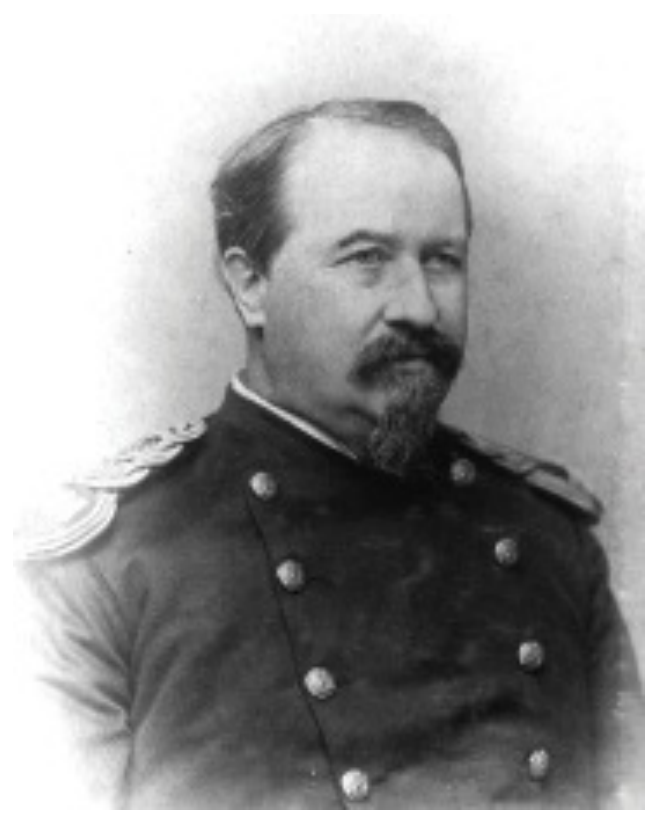

Figure 1. Portrait of Clarence Dutton (courtesy of U. S. Geological Survey archives).

In 1871 Dutton was transferred first to the Frankford Arsenal in Philadelphia, then to the Washington Arsenal where he quickly immersed himself in the vibrant Washington scientific community, focusing his attention on geology (Anderson, 1977; Stegner, 2006; Longwell, 1958). He shortly thereafter was elected a member of the Philosophical Society of Washington and cultivated friendships with those undertaking surveys in the American West. His personal interest in western exploration was sparked by his acquaintance with John Wesley Powell (18341902), who arranged for Dutton's appointment to the Powell Survey [1867-1880: the U.S. Geographical and Geological Survey of the Rocky Mountain Region] through his connections with President Ulysses S. Grant (Stegner, 1954). From 1875 to 1877 Dutton's party mapped fully 
12,000 square miles of plateau country at a scale of 1:250,000 and topographic contour interval of 250 feet (Longwell, 1958). When the U.S. Geological Survey was established in 1879, Director Clarence King (1842-1901) appointed Dutton to direct the Colorado Division (King, 1880). He spent ten years in geological research in the Colorado Plateau region and coined the term "isostasy" derived from his observations on subsidence and sedimentation (Orme, 2007). His 1882 monograph, the Tertiary History of the Grand Canyon District, is renowned for its particular charm, with sublime landscape descriptions and superb illustrations (Figure 2) by artists Thomas Moran (1837-1926) and William Henry Holmes (1846-1943).

In 1884 Powell appointed Dutton to oversee studies in volcanic geology. He had in 1882 spent several months in Hawaii in preparation for this position, hoping to gain the experience of witnessing active volcanism (Dutton, 1884). He provided detailed and engaging descriptions of volcanism and geomorphology on all of the major islands and anecdotal historical descriptions of eruptions witnessed by visitors and natives. In 1884 he mapped in the vicinity of Mount Taylor in northwestern New Mexico, dispatching Joseph Silas Diller (1850-1928) to initiate studies in the Cascades of California and Oregon (Diller, 1912). In 1886 he became the first man to bring in boats in order to plumb and measure Crater Lake (Stegner, 1937). However, later in 1886 Powell directed Dutton to study the effects of the catastrophic Charleston Earthquake of 31 August 1886, and Diller assumed leadership of USGS Cascade volcanic studies. Although Dutton visited the Cascades and wrote short notes concerning their geology (Dutton, 1885b, 1886), he never again engaged in full-scale research in the region.

In the following years Dutton was in charge of irrigation investigations, ever a research focus of Powell's. He supervised seven divisions of engineers and by 1890 had designated 142 reservoir sites, surveyed 300 miles of canals and had reported 30 million acres of land as irrigable (Anderson, 1977). However, political meddling by Congress, the slowness of the process by which irrigable lands could be opened for settlement under the Homestead Law, the inability to check the migration of settlers to the frontier and disagreement with Powell on the utility of regional scale topographic mapping in the construction of reservoirs and canals led to discord among Powell's ranks. In the end Congress scrapped the Irrigation Survey and the USGS suffered a period of budgetary crisis (Rabbitt, 1980). Dutton was recalled to active service with the rank of major by the War Department in 1890, ending his Survey career.

Dutton was included as a geologist in inspection of a proposed canal route across Nicaragua in 1891, assessing seismic and volcanic hazards (which he dismissed), which resulted in his endorsement of the feasibility of the canal project (Dutton, 1892; Halliday, 2008). While on duty in Texas he made frequent excursions to the volcanoes of Mexico (Diller, 1912). Declining health forced his retirement from the Army in 1901. Following retirement he authored a basic text entitled Earthquakes in the Light of the New Seismology (Dutton, 1904) for the 'Progressive Science Series' of the John Murray Publishing House that reviewed both old and modern concepts. In a review of this text (R.D.O., 1905, p. 320) Dutton is cited as "a master of the old seismology [with] a thorough knowledge of, and sympathy with, the new [who has] produced what is indubitably the best handbook of seismology now available." Dutton concluded (1904, p. 37 ) that as yet geologists "have indications of more or less unrest of the earth's interior which we find it hard to explain. Volcanic action itself is not yet understood and we have no satisfactory theory of it." Shortly thereafter he proposed that the heat for magma genesis was derived from radioactivity that resolved the volcanic problem, which he had confronted for over thirty years (Dutton, 1906). He died on January 4, 1912, following a battle with arteriosclerosis. Though austere, he was an idealistic, kind and generous man who was intensely fond of discussion on a 
wide range of subjects. His last message, in an autobiographical letter, was "[f]arewell to my old friends on the Geological Survey" (Diller, 1912, p. 16).

Stegner (1937) notes that six national parks owe something of their history to Dutton: Grand Canyon, Zion, Bryce, Lassen Volcanic, Crater Lake and Hawaii Volcanoes, and that much of his geologic interpretations remain intact. He assigned oriental names to various buttes and towers within the Grand Canyon, such as "Shiva's Temple" and "Ottoman Amphitheater" (Stegner, 1937). Of his literary skill, Stegner $(2006$, p. 5, 10) notes that: "When writing his books he never used notes, but mulled his subject over until all its parts fell into regular order. Then he wrote rapidly and from memory, and he practically never had to revise. . . . Dutton's works . . . are probably the finest things from the standpoint of literary merit in the whole history of American geology."

\section{STRATIGRAPHY AND DENUDATION OF THE COLORADO PLATEAU}

Dutton (1879, 1882a, 1882b, 1882c), mapping chiefly in the Colorado Plateau as part of the Powell Survey (Figure 3) and later working for the U.S. Geological Survey, was impressed by the lateral continuity of formations. He emphasized that (Dutton, 1882c, p. 7): "The beds are remarkable for their homogeneity and constancy of character over vast areas, though the different formations vary greatly in lithological character; that is to say, homogeneity in horizontal range, with great heterogeneity in vertical range." His view of the stratigraphic record emphasized uniformity (Dutton, 1882c, p. 208):

As we trace the individual beds from place to place, we find their composition to be as persistent as their thickness. The sandstone of a given horizon is always and everywhere a sandstone, the limestone a limestone, the shale a shale. Even the minuter $[s i c]$ structure of the beds is similarly maintained, and features which are almost abnormal are equally constant.

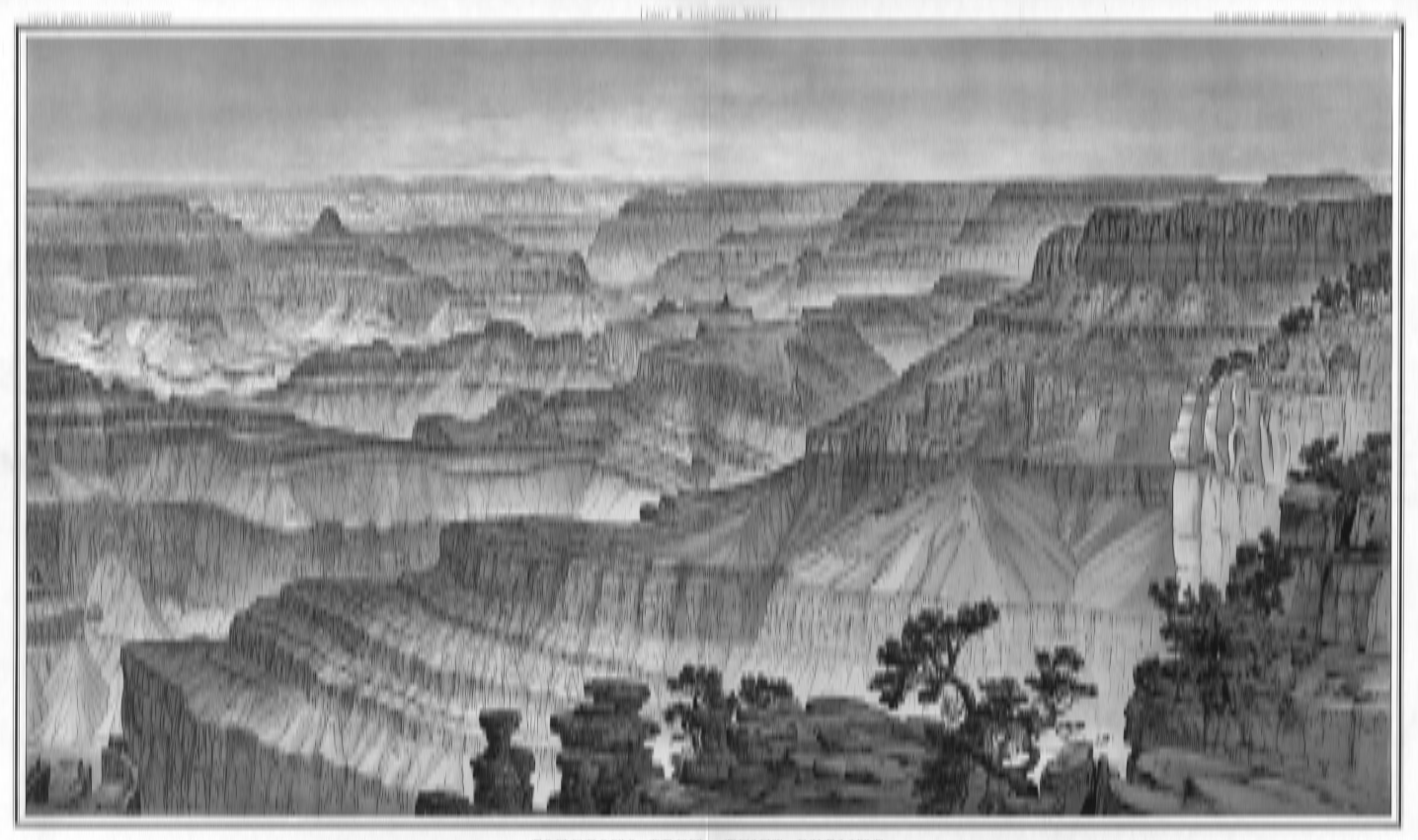

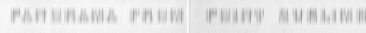


Figure. 2. Grayscale reproduction of a panoramic sketch of the Grand Canyon drawn by W. H. Holmes (Dutton, 1882a, composite of map sheets XV-XVII).

Dutton's (1882b, p. 65-66) stratigraphic observations led him to conclude that all Paleozoic and Mesozoic rocks were deposited at or close to sea level, chiefly in a shallow marine setting:

From the close of the Carboniferous to the close of the Cretaceous there is strong evidence that the surface of deposition was always very near to sea level, sometimes a few feet above it, but for the most part a little below it. And yet in the interval of about 9,000 feet of strata accumulated with remarkable uniformity over the entire province, and always in the horizontal position. ... At the close of the Cretaceous . . . some extensive disturbances took place, resulting at some places in the dislocation and flexing of the strata, and the elevation of some portions of the region to considerable altitudes. ... At some of these places the entire local Cretaceous series was denuded, and even a portion of the Jurassic; and the Tertiary is seen lying upon the Jurassic and across the beveled edges of the flexed Cretaceous strata.... From that epoch to the present time there has been no recurrence of marine conditions. ... Through Eocene time from 1,000 to 5,000 feet of lacustrine beds ... were deposited. Among them are also found layers of coal and carbonaceous shales, and sandstones thickly imprinted with the traces of arboreal vegetation.

Dutton believed that crystalline plutonic and metamorphic rocks exposed in the cores of many mountain ranges were indeed Archean in age, that a landscape of considerable relief existed at the advent of the Paleozoic Era when seas rose to inundate the continent, and that Archean topography exerted a strong control on sediment deposition. His discussions of Paleozoic-Mesozoic marine sedimentation and geologic profiles are consistent with James Dwight Dana's (1813-1895) view (Dana, 1875, p. 102) that the "prevailing depositions" [italics his] of specific lithologies might have been maintained over great regions in the seas of a continent.

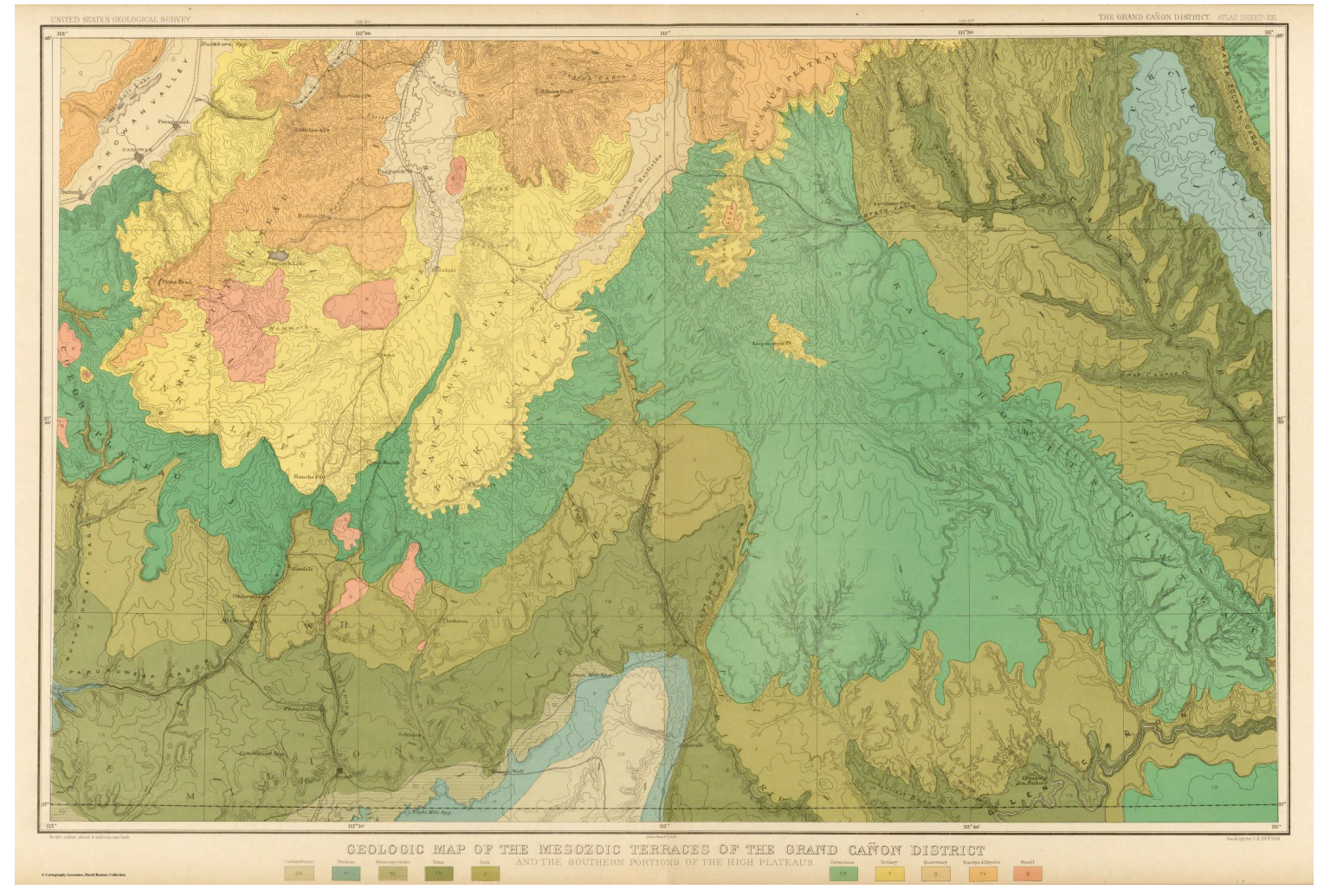


Figure. 3. Geologic map of the Mesozoic terraces of the Grand Cañon District and the southern portions of the high plateaus (Dutton, 1882a, sheet XXI; atlas scale: 1:250,000here reduced to fit on a journal page).

Dutton (1882b, p. 62) recognized that throughout the Colorado Plateau "the structural deformations of the surface, the uplifts and downthrows had nothing to do with determining the present distribution of Plateau drainage." In other words, the major rivers were antecedent and downcut as uplift occurred. Dutton (1882b, p. 96) speculated upon balance between erosion and sedimentation during regional denudation:

Erosion and sedimentation are the two half phases of one cycle of causation-the debit and credit sides of one system of transactions. The quantity of material which the agents of erosion deal with is in the long run exactly the same as the quantity dealt with by the agencies of deposition; or, rather, the materials thus spoken of are one in the same. If, then, we would know how great have been the quantities of material removed in any given geological age from the land by erosion, we have only to estimate the mass of the strata deposited in that age.

Dutton (1882b, p. 102) believed that the thickness of the strata removed from a region in a given period of erosion should be proportional to the amount of relief in the profiles of the country, and that:

All regions are tending to base-levels of erosion, and if the time be long enough each region will, in its turn, approach nearer and nearer, and at last sensibly reach it. ... But the greater portion of the existing land of the globe ... has been subject to repeated throes of elevation or depression. Such a change ... at length destroys the preexisting relation of a region to its base-level of erosion. If it is depressed it becomes immediately an area of deposition. If it is elevated new energy is imparted to the agents and machinery of erosion.

He determined that during the great denudation of the "Grand Cañon District" occurred during rising of the region throughout almost the entire stretch of Tertiary and Quaternary. However, uplift was not at a uniform rate. A definite period of quiescence (Dutton, 1882b, p. 103) "occurred probably in late Miocene or early Pliocene time, and while it prevailed the great Carboniferous platform was denuded of most of its inequalities, and was planed down to a very flat expanse. Since that period the relation has been destroyed by a general upheaval of the entire region several thousands of feet." The great British geologist, Sir Archibald Geikie (18351924) met Powell and Dutton while traveling in the American West and was profoundly impressed by their advocacy of the immense landscape degradation by fluvial processes, concluding that in the British Isles "geologists had been blind to the geomorphic significance of rain and river action" (Davies, 1969, p. 352).

\section{VOLCANISM ON THE COLORADO PLATEAU}

The high plateaus of Utah, the focus of Dutton's field research from 1875-1877 following his Grand Canyon work, are a great volcanic area in which eruptions have occurred upon a grand scale. The period of activity had been a very long one, its initial epoch having been not far from the Middle Eocene; and the eruptions have occurred with probably long intervals of repose throughout the remainder of Tertiary and Quaternary time. Dutton (1880) observed that the variety of eruptive products is exceedingly great, all of the commoner kinds from the very acid to the very basic groups being well represented. The preponderating masses were trachytic, but rhyolites, andesites and basalts are found in great abundance. He did not find it credible that the 
sources of eruptive materials were located in reservoirs at very great depth and that a fixed, universal compositional progression of magmas were erupted over time as these reservoir were tapped, as had been postulated for the American West by Baron Ferdinand von Richthofen (1833-1905) (Von Richthofen, 1868; Aalto, 2008). Instead, he viewed volcanic eruptions as local phenomena, with degree of compositional variation between and among eruptive centers reflecting magma derivation by fusion of varied source rocks (Dutton, 1880, p. 124-125):

And in general our inference ... is that the lavas do not emanate from an earth-nucleus wholly liquid, nor from great subterranean reservoirs still left in a liquid condition, but from the secondary fusion of rocks, a part of which may have formed the primitive crust, while the remaining part consisted of deeply-buried and metamorphosed sedimentary strata. ... We must at least admit that the source of lavas is among segregated masses of heterogeneous materials [italics his].

At the end of his life Dutton recognized that radioactivity was perhaps the vital missing link in volcanism (Halliday, 2006). Noting (Dutton, 1906, p. 260-261) "the comparative smallness of extravasated masses in any single volcanic eruption" and the repetitive nature of eruptions "at any one site, and seismic evidence suggesting "that most of the volcanic eruptions originate at depths between one mile and two and one-half miles" he concluded (Dutton, 1906, p. 262) that radiogenic heat provides a logical source for magma:

[A] development of heat, resulting from radioactivity, in limited tracts at a depth of one to three ... miles from the surface, which is sometimes sufficient to melt the rocks affected by it. The melting is gradual, and when a sufficient quantity is melted, the water which it contains becomes explosive and usually suffices to break through the covering, constituting an eruption. ... If the heat continues to be generated, more lava is melted, and in due time another eruption occurs... The volcanic action may continue in the same place for hundreds of thousands, or even millions, of years.

This view contrasted with the then traditional one (Dutton, 1906, p. 262) "that the lava reservoirs are a part of the original constitution of the earth, and have lain in their present position through all the vast period of the earth's evolution, waiting for a convenient occasion to explode and pour forth their fiery contents."

\section{THE GREAT CHARLESTON EARTHQUAKE}

In his summary report on the1886 Charleston earthquake Dutton (Dutton, 1889b) included a number of anecdotal accounts written by those who experienced the event and described the ensuing damage. He built upon preliminary investigations of USGS employees William John McGee (1853-1912), Thomas Corwin Mendenhall (1841-1924) and, especially, Earle Sloan (1858-1926) who had visited the site prior to his arrival with authorization from Powell (Côté, 2007). Although at the time of the quake there were no seismographs operating, clocks had previously been standardized at telegraph stations throughout the country. Dutton profited from this standardization because "for the first time in all history, a man could coordinate the facts [timing] about such a catastrophe" (Bartlett, 1966, p. 318). In response to a plea by the USGS, reports of the timing of tremors were provided and Dutton was able to establish the velocity of earthquake wave propagation at $3.22 \mathrm{miles} / \mathrm{second}$. This value corresponded with that calculated for a homogeneous, siliceous solid earth. 
Liquefaction was extensive due to extensive buried estuarine and marine sands underlying the city. By analyzing (Dutton, 1889b, p. 353) patterns of damage and displacement among man-made structures he determined that two distinct foci existed (Figure 4): "A system of isoseismals as here contemplated would express the relation between two variables, viz: (1) the distance from the epicentrum and (2) the intensity, or some function of the intensity, measured in units of energy." By noting (Dutton, 1889b, p. 313) "the variation of intensity along lines radiating from the epicentrum ought to manifest an approximate agreement with a theoretical law ... from which [epicentral] depth could be inferred. ... The greatest resulting depth of a focal point is about twelve miles, with a probable error of less than two miles." Dutton (1904) distinguished two types of earthquakes, those of volcanic verses those of tectonic origin, devoting an entire chapter to each of these classes. 


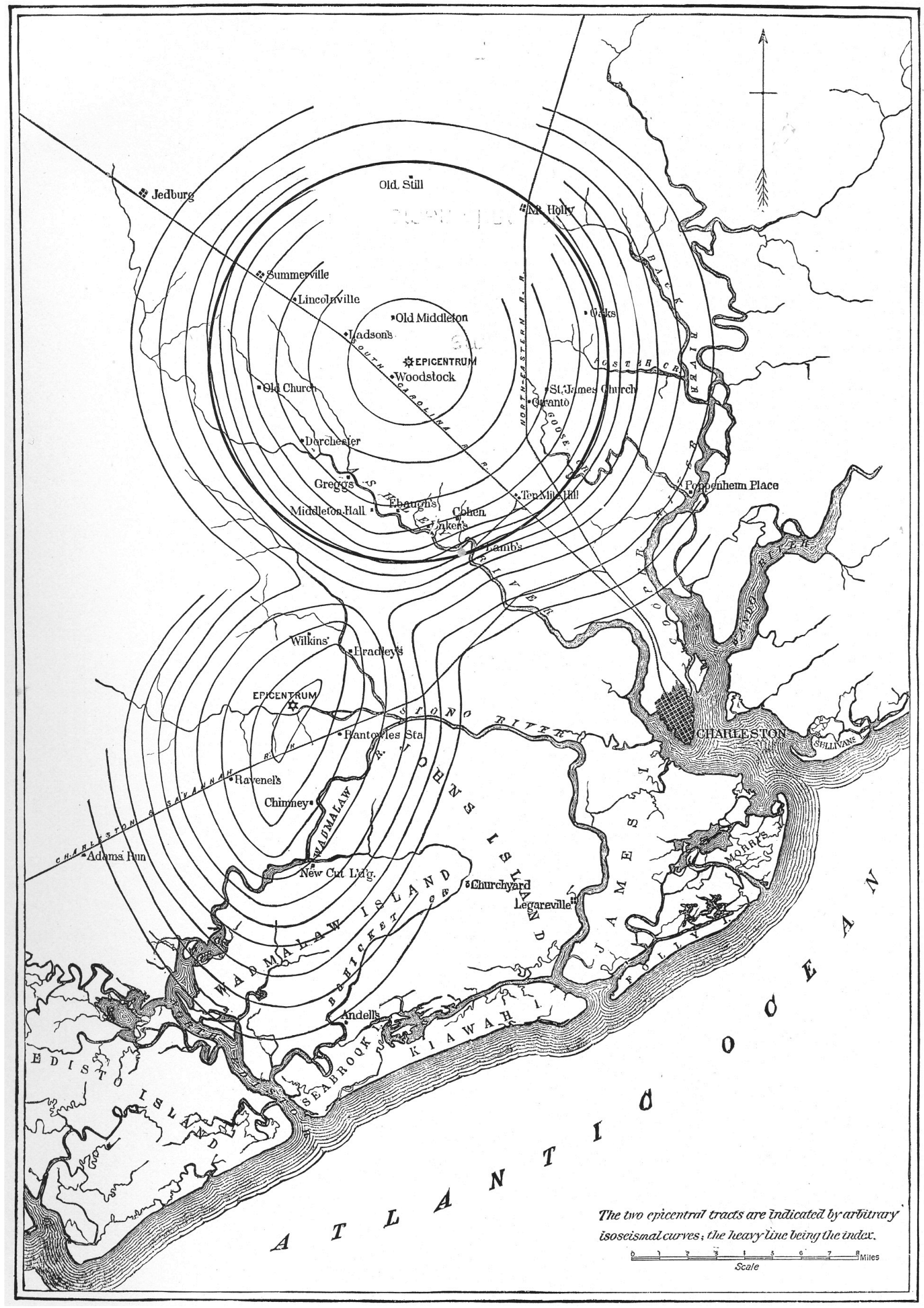




\title{
Figure. 4. Isoseismals within the epicentral tracts (Dutton, 1889b, plate 26, based upon the work of Earle Sloan).
}

\author{
Davison (1978, p. 149) felt that " $[t]$ he outstanding results of the investigation fall
} under three headings - (i) the determination of the double epicenter, (ii) the attempt to ascertain the depths of the corresponding foci, and (iii) the estimate of the mean velocity of the earth-waves." However, Davison (1978, p. 149) categorized Dutton's 1904 seismology text as a popular work, "not quite representative of our knowledge at the beginning of the century".

\section{ISOSTASY}

In his Grand Canyon research Dutton witnessed the effects of sediment loading of the crust, concluding that the resulting depression was logically linked to uplift of adjacent areas (Dutton, 1880, p. 13-14):

It is incredible that the Cretaceous ocean at the commencement of that age could have had a depth equal to the thickness of the strata and that the sediments filled it up. The facts are wholly against such a supposition, and point clearly to shallow waters. The only conclusion which appears tenable is that the strata sank as rapidly as they were deposited. . . . It was from these ranges [to the north] that the heaviest masses of the Cretaceous-Eocene sediments were derived. As fast as, or even faster than, the mountains were devastated to supply mass for the new strata, they continued to rise. But if they rose, fresh matter must have been thrust under their foundations, replacing the rising strata. Whence came the replacing matter? It may be premature as yet to say that the elevation of the mountains and subsidence of the strata are correlated in the way which these inquiries suggest, but the juxtaposition of the facts must be regarded as significant.

Dutton (1889a, p. 53) proposed the term isostasy to describe a "condition of equilibrium of figure, to which gravitation tends to reduce a planetary body, irrespective of whether it be homogeneous or not." Such ideas of flotation had been around since the mid- $19^{\text {th }}$ Century. Dutton's thinking was strongly influenced by Osmond Fisher's Physics of the Earth's Crust (1881), which he reviewed in 1883 (Greene, 1982). However, Oldroyd (1996) felt that Dutton refined the concept considerably.

Noting that "where great bodies of strata are deposited they progressively settle down or sink seemingly by reason of their gross mechanical weight" (Dutton, 1889a, p. 54), he invoked isostatic compensation to explain the immense thicknesses of sediments that were accumulated both in the Appalachians during the Paleozoic and the Colorado Plateau, yet whose character suggests deposition in a shallow marine setting. Dutton (1889a, p. 55-56) noted that a reciprocal relation exists wherever uplifted platforms occur that have been subjected to great erosion, with the loss of altitude by degradation made good by a rise of the platform. Western mountain ranges situated upon broad, high platforms, whose flanks have "upturned edges of the strata reposing against them or with gigantic faults measuring their immense uplifts, [that] plainly declare to us that they have been slowly pushed upwards as fast as they were degraded by secular erosion." However, he doubted that "these subsidences of accumulated deposits and these progressive upward movements of eroded mountain platforms are, in the main, results of gravitation restoring the isostasy which has been disturbed by denudation on the one hand and by sedimentation on the other." 


\section{OROGENY}

Dutton (1889b) cited the causes of volcanic action and regional crustal shortening as two of the unsolved problems in physical geology. He disavowed the hypothesis that linear contractional orogens originated as a result of collapse and buckling of the crust upon the shrinking nucleus of the earth, a hypothesis championed by the highly influential James Dwight Dana (Dott, 1997). Dutton presented mathematical analysis to demonstrate that if one assigned thirty miles as the diminution of the earth's mean radius since the first formation of a cooled exterior, a figure consistent with heat flow and rock materials data known at the time, "by far the larger portion of this contraction must have taken place before the commencement of the Paleozoic age. By far the larger portion of the residue must have occurred before the beginning of the Tertiary; and yet the whole of this contraction would not be sufficient to account for the disturbances which have occurred since the close of the Cretaceous" (Dutton, 1874, p. 121).

He noted that in the Appalachian fold and thrust belt systematic plication [folding] is reflected in northwest-directed shortening, whereas forces which would arise from a crust collapsing around a shrinking earth interior should exhibit no such determinate direction. However, he speculated (Dutton, 1889a, p. 60) that focused loading adjacent to a landmass might engender directed stress normal to its margin: "[t]he effective force .... tends to push the loaded sea bottoms inward upon the unloaded land horizontally." He was strongly influenced by James Hall's (1811-1898) belief that there was a clear-cut causative relationship between depositional belts and orogenesis, that " $[\mathrm{i}] \mathrm{t}$ is original deposition that not only gives direction to the mountain chains, but amount of deposition that determines their elevation ... there can be no great degree of elevation without a corresponding amount of previous deposition of sediments" (Hall, 1882, p. $55)$.

He felt that systematic plication in orogenic belts occurs only among sedimentary beds of great thickness which were rapidly accumulated, that they occur in their systematic form along ancient shore lines, that the formative forces acted in one direction and that these flexures were mainly formed at the times the sediments were deposited. Thus "[t]hese plications, according to isostatic theory, are the results of the disturbance of isostasy, and follow immediately upon that disturbance or after it has reached a sufficient amount, and cease with it." Conversely, "[t]he contractional theory gives a force having neither direction nor determinate mode of action, nor definite epoch of action" (Dutton, 1889a, p. 62).

Dutton (1889a, p. 63) rejected "the habit of geologists to attempt to explain the progressive elevation of plateaus and mountain platforms, and also the foldings [sic] of the strata by one and the same process.... There are plicated regions which are little or not at all elevated, and there are elevated regions which are not plicated." This echoes Dana's criticism of Hall's genetic link between sedimentation and orogeny, that the flexing of Appalachian rocks took place postdepositionally, rather than progressively during their deposition. The real nature of the uplifting force remained a mystery, but perhaps, "the cause which elevates the land involves an expansion of the underlying magmas, and the cause which depresses it is a shrinkage of the magmas" (Dutton, 1889a, p. 64).

While systematic plication was characteristic of such orogenic belts as the Appalachians, Dutton (1885a, p. 196-198) did not observe it in the Plateau Region:

The terms anticlinal and synclinal have almost dropped out of the vocabulary of the western geologist. The strata are often flexed, but the type of flexure is the monocline... . The country at large shows no traces of a widespread, universal horizontal compression; on the contrary, it discloses the absence of such stress... We seem here to get 
nearer to the real nature of the process which has built the mountains.... The mountains of the West have not been produced by horizontal compression, but by the action of some unknown forces beneath which have pushed them up.

Dutton (1885a, p. 196) recognized, as had Clarence King in his Fortieth Parallel Survey (Aalto, 2004), that even where extensive folds occur they are wholly dissociated from mountain uplift, that "flexures belong to ancient disturbances, some of the Mesozoic others Paleozoic, while the hoisting of the ranges is much more recent, being mainly Middle and Late Tertiary."

For years Dutton speculated that volcanism, metamorphism and magma genesis were linked by process, that metamorphism and volcanism are the same process acting under slightly varied conditions. In mapping Mount Taylor on the Zuni Plateau of Utah, Dutton believed that the crystalline granitic rocks were exclusively Archean in age and that what we now view as intrusive contacts could be explained by heating and tectonic kneading-in of the older crystalline rocks into superjacent sediments (Dutton, 1885a). This accords with his earlier hypothesis that granitoid cores of many mountain ranges were mobilized and extruded accompanying extensive and rapid episodes of sediment loading upon older rock masses (Dutton, 1876). However, Dutton (1904, p. 33) concluded "isostasy is the tendency to maintain profiles in equilibrium, not to raise or lower them. What are commonly spoken of as upheavals and depressions are due to some cause or causes not yet understood."

\section{DISCUSSION}

G. K. Gilbert (1843-1918) popularized scientific methodology of the late 19th Century in what came to be called the method of multiple working hypotheses. His method (Gilluly, 1963, p. 221) involved: "(1) observing the phenomenon to be studied and systematically arranging the observational data, (2) inventing hypotheses regarding the antecedents of the phenomena, (3) deducing expectable consequences of the hypothesis, and (4) testing these consequences against new observations."

Dutton's science serves as an exemplar of this methodology. The geologic history of the Colorado Plateau was deduced from stratigraphic data according to the prevalent hypothesis of uniformitarianism. Speculations on the efficacy of fluvial denudation and the balance between erosion and sedimentation during regional denudation were based upon topographic study that, combined with mass balance calculations, linked sediment loading, depression of the crust and uplift of adjacent areas, antecedents of the hypothesis of isostasy. His field observation volcanic rocks led him to conclude that volcanic eruptions are local phenomena, with compositional variation reflecting fusion of varied source rocks. While able to deduce the effects of erosion and sedimentation on uplift and depression, he concluded that at present no working hypothesis adequately linked isostasy, seismicity, volcanism and regional deformation, thus that the significance of orogeny remained unresolved.

Despite retaining his military ties throughout his career, Clarence Dutton essentially served as a U. S. Geological Survey scientist during the pioneering days of western exploration. His diverse interests and ability to write creatively and complete projects in a timely manner resulted in his authorship of a half dozen of the best-illustrated and most readable Survey reports of the 1880 's. 


\section{ACKNOWLEDGEMENT}

The Atlas to Accompany the Monograph on the Tertiary History of the Grand Cañon District is provided on line to the general public courtesy of the David Rumsey Historical Map Collection $<$ www.davidrumsey.org $>$.

\section{REFERENCES}

Aalto, K. R., 2004, Clarence King's geology: Earth Sciences History, v. 23, p. 9-31.

Aalto, K. R., 2008, A natural order of volcanic succession: mid-nineteenth century fieldbased models of Von Richthofen, King and Dutton: Earth Sciences History, v. 27, p. 59-77.

Anderson, R. S., 1977, A Biography of Clarence Edward Dutton (1841-1912), nineteenth century geologist and geographer [M.S. thesis]: Stanford University, $126 \mathrm{p}$.

Bartlett, R. A., 1966, Great Surveys of the American West: Norman, University of Oklahoma Press, 408 p.

Côté, R. N., 2007, City of Heroes: Mt. Pleasant, SC, Corinthian Books, 542 p.

Dana, J. D., 1875, Manual of Geology: New York, Ivison, Blakeman, Taylor \& Co., 828 p.

Davies, G. L., 1969, The Earth in Decay: A History of British Geomorphology 1578-1878: London, MacDonald Technical and Scientific, 408 p.

Davison, Charles, 1978, The Founders of Seismology: New York, Arno Press, 240 p.

Diller, J. S., 1911, Major Clarence Edward Dutton: Bulletin of the Seismological Society of America, v. 1, p. 136-142.

Diller, J. S., 1912, Memoir of Clarence Edward Dutton: Geological Society of America Bulletin, v. 24, p. 10-18.

Dott, R. H., Jr., 1997, James Dwight Dana's old tectonics-global contraction under divine direction: American Journal of Science, v. 297, p. 283-311.

Dutton, C. E., 1874, A criticism upon the contractional hypothesis: American Journal of Science, v. 8, p. 113-123.

Dutton, C. E., 1876, Critical observations on theories of the earth's physical evolution: American Journal of Science, v. 13, p. 142-145.

Dutton, C. E., 1879, The geological history of the Colorado River and Plateaus: Nature v. 19, p. 247-252, 272-275.

Dutton, C. E., 1880, Geology of the High Plateaus of Utah: U.S. Geographical and Geological Survey of the Rocky Mountain Region: Washington, Government Printing Office, $307 \mathrm{p}$.

Dutton, C. E., 1882a, Atlas to Accompany the Monograph on the Tertiary History of the Grand Cañon District: U.S. Geological Survey Monograph 2.

Dutton, C. E., 1882b, The physical geology of the Grand Cañon district: U. S. Geological Survey Annual Report 2, p. 47-166.

Dutton, C. E., 1882c, Tertiary History of the Grand Cañon District [2001 facsimile edition of U. S. Geological Survey Monograph 2]: Tucson, University of Arizona Press, $264 \mathrm{p}$.

Dutton, C. E., 1884, Hawaiian volcanoes: U. S. Geological Survey Annual Report 4, p. 
81-219.

Dutton, C. E., 1885a, Mount Taylor and the Zuni Plateau: U. S. Geological Survey Annual Report 6, p. 105-198.

Dutton, C. E., 1885b, The latest volcanic eruption in the United States: Science v. 6, p. 46-47.

Dutton, C. E., 1886, Crater Lake, Oregon, a proposed national reservation: Science v. 7, p. $179-182$.

Dutton, C. E., 1889a, On some of the greater problems of physical geology: Philosophical Society of Washington Bulletin 11, p. 51-64.

Dutton, C. E., 1889b, The Charleston earthquake of August 31, 1886: U. S. Geological Survey Annual Report 9, p. 203-528.

Dutton, C. E., 1892, Report on the Nicaragua Canal: U. S. Government Documents, 52nd Congress, 1st Session, Senate Miscellaneous Document 97, p. 1-24.

Dutton, C. E., 1904, Earthquakes in the Light of the New Seismology: London, John Murray, $314 \mathrm{p}$.

Dutton, C. E., 1906, Volcanoes and radioactivity: Journal of Geology, v. 14, p. 259-268.

Gilluly, J., 1963, The scientific philosophy of G. K. Gilbert: in Albritton, C. C., Jr., ed., The Fabric of Geology: Stanford, CA, Freeman, Cooper \& CO., p. 218-224.

Greene, M. T., 1982, Geology in the Nineteenth Century: Ithaca, Cornell University Press, 324 p. Hall, J., 1882, Contributions to the Geologic History of the American Continent: Salem, MA, Salem Press. (A transcription of his Presidential Address to the American Association for the Advancement of Science in August, 1857).

Halliday, W. R., 2006, Clarence Edward Dutton: geologist, Major of Ordnance, man of letters: Geological Society of America Abstracts with Programs, v. 38, p. 302.

Halliday, W. R., 2008, Clarence Edward Dutton (1841-1912): GSA Today, v. 18, p. 4849.

King, C., 1880, First Annual Report of the United States Geological Survey: Washington: U.S. Government Printing Office, 79 p.

Longwell, C. R., 1958, Clarence Edward Dutton, May 15, 1841-January 4, 1912 : National Academy of Sciences Biographical Memoirs, v. 38, p. 132-145.

Oldroyd, D. R., 1996, Thinking About the Earth: Cambridge, Harvard University Press, $410 \mathrm{p}$.

Orme, A. R., 2007, Clarence Edward Dutton (1841-1912): soldier, polymath and aesthete, in Wyse-Jackson, P., ed., Four centuries of geological travel: the search for knowledge on foot, sledge and camel: Geological Society of London Special Publication 287, p. 271-286.

R.D.O., 1905, The new seismology: two new text-books: Geographical Journal, v. 25, p. 320-323.

Rabbitt, M. C., 1980, Minerals, Lands, and Geology for the Common Defence and General Welfare. Volume 2, 1879-1904: Washington, U.S. Government Printing Office, $407 \mathrm{p}$.

Stegner, W., 1937, C. E. Dutton-explorer, geologist, nature writer: Scientific Monthly v. 45, p. $82-85$.

Stegner, W., 1954, Beyond the Hundredth Meridian: Boston, Houghton Mifflin.

Stegner, W., 2006, Clarence Edward Dutton: An Appraisal: Salt Lake City, University of Utah Press, 23 p. 
Von Richthofen, Ferdinand, 1868, The natural system of volcanic rocks: California Academy of Sciences memoir 1, part II, 94 p. 